\title{
Natural establishment of Eucalyptus globulus Labill. in burnt stands in Portugal
}

\author{
Ana Águas ${ }^{\mathrm{a}, \mathrm{b}, *}$, António Ferreira ${ }^{\mathrm{a}}$, Paula Maia ${ }^{\mathrm{c}}$, Paulo M. Fernandes ${ }^{\mathrm{a}, \mathrm{d}}$, Luís Roxo ${ }^{\mathrm{d}}$, Jan Keizer ${ }^{\mathrm{c}}$, \\ Joaquim S. Silva ${ }^{a, e}$, Francisco C. Rego ${ }^{a}$, Francisco Moreira ${ }^{a}$ \\ a Universidade de Lisboa, Instituto Superior de Agronomia, Centro de Ecologia Aplicada "Prof Baeta Neves", InBio, Tapada da Ajuda, $1349-017$ Lisboa, Portugal \\ ${ }^{\mathrm{b}}$ Instituto Politécnico de Leiria, Escola Superior de Educação e Ciências Sociais, 2411-901 Leiria, Portugal \\ ' CESAM, Departamento de Ambiente e Ordenamento, Universidade de Aveiro, 3810-193 Aveiro, Portugal

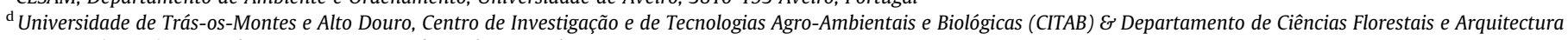 \\ Paisagista (CIFAP), Apartado 1013, 5001-801 Vila Real, Portugal \\ e Instituto Politécnico de Coimbra, Escola Superior Agrária, 3040-316 Coimbra, Portugal
}

\section{A R T I C L E I N F O}

\section{Article history:}

Received 23 December 2013

Received in revised form 5 March 2014

Accepted 6 March 2014

Available online 17 April 2014

\section{Keywords:}

Eucalyptus globulus

Wildfire

Post-fire management

Seed

Establishment

Naturalization

\begin{abstract}
A B S T R A C T
Exotic tree species are increasingly common in many regions of the world and at least some species are becoming naturalized in the regions where they were introduced. Disturbances like fire may be at the origin or accelerate the naturalization of these species. Portugal holds one of the largest areas of exotic Eucalyptus globulus plantations in the world and is one of the countries most affected by forest fires. These two facts have triggered the present research. This study aimed at characterising medium-term natural establishment of E. globulus plants originated from seeds under natural conditions in burnt planted forests (pure E. globulus stands, pure Pinus pinaster stands, and mixed stands of both species), and at analysing factors associated with this establishment. Occurrence, abundance and height of naturally established E. globulus plants were characterized in 284 sites distributed in burnt areas, across Central and Northern Portugal, 57 years after wildfire. Generalized linear models were used to assess the influence of stand type, regional productivity potential, and post-fire management practices on occurrence probability, density, and median height of sampled E. globulus individuals. The influence of these explanatory variables on the structure (in terms of size class distribution) of naturally established E. globulus cohort was examined using analysis of similarity and non-metric multidimensional scaling. Naturally established E. globulus plants were present in $93.1 \%, 19.0 \%$ and $98.6 \%$ of samples in pure E. globulus, pure $P$. pinaster and mixed stands, respectively. Cohort median density was 0.20 plants $\mathrm{m}^{-2}$ and maximum density was 4.55 plants $\mathrm{m}^{-2}$. Median height of plants was $2.0 \mathrm{~m}$ and $95.3 \%$ of them had $h>1.30 \mathrm{~m}$ and DBH $\leqslant 5 \mathrm{~cm}$. Establishment probability, density and median height were highest in the most productive regions. Three post-fire management operations had a significant influence on the response variables: (i) salvage logging was associated with a higher density; (ii) tillage was associated with a lower density and a smaller median height; (iii) understorey removal was associated with a lower occurrence probability. Tillage was the only studied factor influencing the size structure of spontaneously established cohort, eliminating larger plants. This study showed that stand type, productivity region and post-fire management operations might have significantly influenced the natural establishment of $E$. globulus in burnt areas, and consequently the species naturalization process in Portugal. The implications of these findings for management are discussed.
\end{abstract}

(c) 2014 Elsevier B.V. All rights reserved.

\section{Introduction}

Given the expansion of exotic tree plantations in the world (MCPFE, 2007; FAO, 2010), the study of ecological processes

\footnotetext{
* Corresponding author. Address: Centro de Ecologia Aplicada Prof. Baeta Neves, Instituto Superior de Agronomia, Tapada da Ajuda 1349-017 Lisboa, Portugal. Tel.: +351 213653333; fax: +351 213653290 .

E-mail address: ana.aguas@ipleiria.pt (A. Águas).
}

associated with these forests is increasingly important. Some of the most relevant issues are related to naturalization or invasive potential of exotic tree species, since significant interactions with the native ecosystems are possible (Richardson, 1998). Disturbances in general and fire in particular are known to facilitate the recruitment of different exotic species (e.g. Anderson and Brown, 1980; Mandle et al., 2011; Arianoutsou and Vilà, 2012; Vallejo et al., 2012). Therefore, the fire-mediated naturalization of planted exotic trees is a relevant research topic (Silva and Marchante, 2012). 
Eucalyptus globulus Labill. (Tasmanian blue gum) is one of the most widely planted and economically important hardwood species in temperate regions of the world (Potts et al., 2004). This eucalypt is native to SE Australia and it is planted in many regions around the world. Portugal is among the countries that have largest areas of planted E. globulus in the world (Potts et al., 2004). This species was introduced in Portugal in the middle of the 19th century (Radich, 2007) and is now the most widespread tree species in Portuguese mainland, representing $26 \%$ ( $812 \times 10^{3}$ ha) of its forest cover (ICNF, 2013).

E. globulus forests in Portugal are planted and mostly managed through a coppice system (10-12 year rotations) (Turnbull and Pryor, 1984; Soares et al., 2007). Their wood is almost exclusively used for pulp production. Water availability and episodic occurrence of temperatures below $0{ }^{\circ} \mathrm{C}$ are considered the main limiting climatic factors to E. globulus development in Portugal (Almeida et al., 1994; Ribeiro and Tomé, 2000; Alves et al., 2012), where wood yields are very variable due to site conditions and may exceed $30 \mathrm{~m}^{3} \mathrm{ha}^{-1}$ year $^{-1}$ in the very best sites (Tomé, 2000). However, the good adaptation of E. globulus to many Portuguese environmental conditions is having other implications, as the species has become naturalized. The species reproduces by seeds and naturally established plants are commonly found within or close to planted stands nowadays (Marchante et al., 2008; Silva and Marchante, 2012). Although the first reference to naturalization of E. globulus in Portugal dates from 1943 (Almeida and Freitas, 2006), we found no quantitative assessments of this process in the literature. Naturalization processes are known to have resulted in considerable economic and environmental costs for several alien species (Andreu et al., 2009). Naturally established plants may modify ecosystem/plantation dynamics and changes in forest management may be required to control them, since E. globulus grows fast (Silva et al., 2007a). Most of the literature concerning the seed regeneration from E. globulus plantations reports qualitative assessments in order to infer about the naturalization or the invasive status of the species (Ritter and Yost, 2009; Gassó et al., 2010; Gordon et al., 2012). The few references that provide quantitative data are not comparable due to differences on methods and on considered factors (Virtue and Melland, 2003; Calviño-Cancela and Rubido-Bará, 2013; Larcombe et al., 2013).

Fire is often related with eucalypt recruitment and establishment (Mount, 1964; Cremer, 1965; Mount, 1969; Ashton, 1981; Gill, 1997). Causes for fire facilitated recruitment/establishment of eucalypts are related with: increased seed shed from canopy (Cremer, 1965; Pryor, 1976; O’Dowd and Gill, 1984; Wellington and Noble, 1985b; Florence, 1996); seed-predator satiation (O'Dowd and Gill, 1984; Wellington and Noble, 1985b; Gill, 1997); increased light availability (Jacobs, 1955; Kirkpatrick, 1975; Gill, 1997); “ash-bed effect” (Pryor, 1976; Chambers and Attiwill, 1994); reduced competition (Wellington and Noble, 1985a; Whelam, 1995; Gill, 1997); removal of allelopathic substances (Pryor, 1976; Stoneman, 1994); and decreased predator activity (Whelam, 1995). Larcombe et al. (2013) demonstrated that fire was associated with higher recruitment levels of E. globulus, as it had been suggested earlier by Kirkpatrick (1975).

Portugal has the largest percentage of burnt forest area in Europe and one of the largest in the world (FAO, 2010; JRC, 2012) and the National Forest Strategy (DGRF, 2007) indicates that wildfires are a major threat to sustainable forest management in this country. Moreover, eucalypt stands are highly flammable in comparison to other forest systems in Europe and particularly in Portugal (Nunes et al., 2005; Moreira et al., 2009; Silva et al., 2009; Fernandes et al., 2011; Xanthopoulos et al., 2012).

Effects of post-fire operations on seedling establishment depend on how and when they are performed. Post-fire management of burnt forests often includes: salvage logging; tillage; and shrub removal. Post-fire salvage logging usually occurs before establishment of the next generation of trees and its major effects consist of environmental changes derived from removal of burnt trees. If it occurs after seedling establishment, significant seedling mortality can happen (McIver and Starr, 2000). In situ germination of seeds from logging eucalypt slash is common under favourable conditions (Fagg, 2001) and E. globulus plants may establish and grow normally or become dominated trees under coppice shoots (Skolmen and Ledig, 1990). Tillage is aimed at improving soil conditions for root development (Madeira et al., 1989), but in burnt areas can largely enhance erosion, if it is not performed with caution (Coelho et al., 1995; Shakesby et al., 1996). Established plants that were born after fire may be destroyed by tillage (Catry et al., 2010). Few years after fire, understorey is well developed in forests. Since E. globulus is very sensitive to competition with understorey plants especially in early years of life, and fuel load build up increases fire hazard, periodic understorey removal is performed in this species stands (Pereira, 2007; Soares et al., 2007; Moreira et al., 2009; Alves et al., 2012).

To our knowledge, a quantitative assessment of natural establishment of $E$. globulus in burnt areas has never been carried out in Europe. We chose to study the post-fire seminal regeneration of E. globulus because there were recurrent references to fire-induced eucalypt establishment (Jacobs, 1955; Cremer, 1965; Kirkpatrick, 1975; Pryor, 1976; O'Dowd and Gill, 1984; Chambers and Attiwill, 1994; Stoneman, 1994; Florence, 1996; Gill, 1997), as well as frequent observations of E. globulus saplings in recently burnt areas in Portugal (Silva et al., 2007a, 2007b; Silva and Marchante, 2012). Stands with Pinus pinaster were included in the study because this species is highly represented in Portuguese mainland (23\% forest cover) (ICNF, 2013), and it has similarities to E. globulus on its ecological requirements and geographical range. Additional grounds were the common coexistence of these species in mixed stands (Silva et al., 2011) and the high fire proneness of $P$. pinaster stands (pure or mixed) (Moreira et al., 2009).

The study aimed at answering four questions related to medium-term establishment of $E$. globulus plants originated from seeds under natural conditions in burnt forests (pure E. globulus stands, pure $P$. pinaster stands, and mixed stands): (a) what is the likelihood of E. globulus natural establishment in burnt areas; (b) which are the most important factors related with site characteristics, stand type and post-fire management practices influencing this likelihood; (c) how do these variables affect the density of post-fire naturally established $E$. globulus cohort and the median height of its individuals; and (d) how do these variables influence the size structure (distribution of individuals among size classes) of postfire naturally established E. globulus cohort.

\section{Material and methods}

\subsection{Study areas}

Forty areas that had burnt during 2005 and 2006 were selected in Central and Northern Portugal (Fig. 1), regions where E. globulus is common. Burnt areas were identified from existing fire maps created through semi-automated classification of remote sensing satellite data (Marques et al., 2011). Selection of burnt areas was based on time-since-fire (5-7 years), size (largest areas were preferred), accessibility and presence of pure or mixed stands of $E$. globulus and $P$. pinaster (pure stands corresponding to cover of target species $\geqslant 75 \%$, and mixed stands to cover of either species $<75 \%$ ) (AFN, 2009). The selected areas ranged in size from 6 to 10924 ha, with an average of 2078 ha. The sampling grid $(500 \mathrm{~m} \times 500 \mathrm{~m})$ created for the National Forest Inventory (NFI) (AFN, 2010) was used to define potential study sites within the 


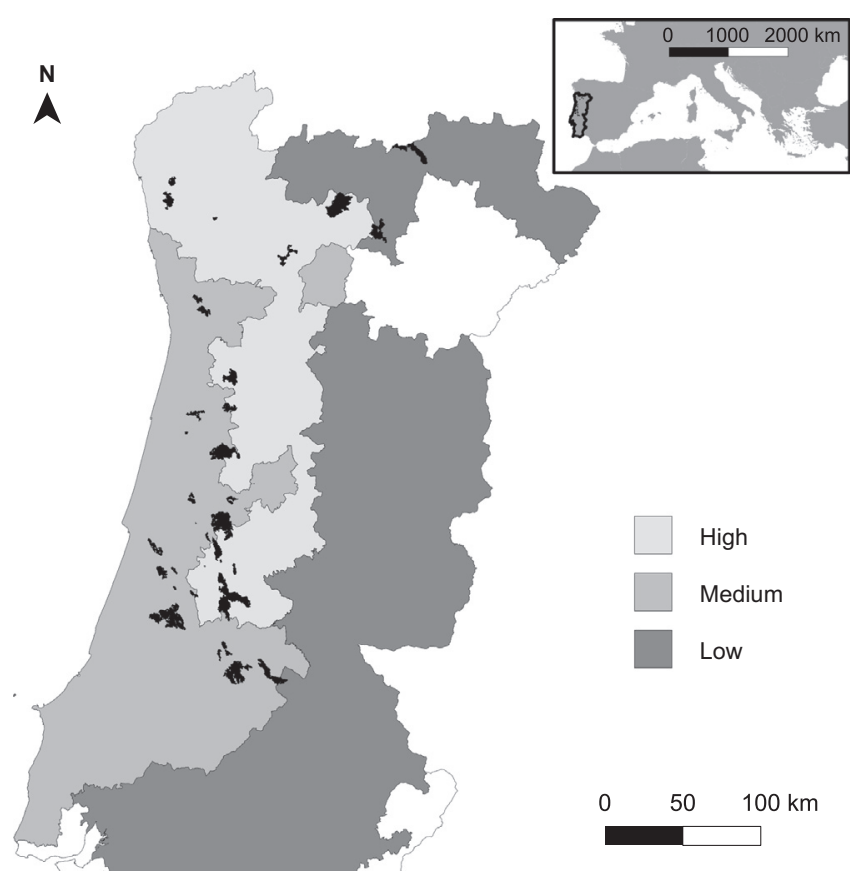

Fig. 1. Location of the 40 studied burnt areas in Portugal (in black). Limits for the three E. globulus productivity regions are also shown (in shades of grey). White areas refer to regions where sampling did not occur.

selected areas. From these potential sites, those corresponding to pure or mixed stands of $E$. globulus and $P$. pinaster were selected, based on pre-2005 NFI data. Depending on the size of the selected areas, up to 30 sites were chosen per area. The selected sites were checked in the field for eventual land cover changes after fire, and the ones that had been converted to other land uses after fire were excluded. A total of 321 sites was obtained (range $=1-30$ sites per burnt area): 37 for refining sampling method (data not presented), and 284 for definite sampling.

\subsection{Field sampling}

Sites were sampled between June 2010 and June 2012. The sampling design was an adaptation of the method used in Portuguese National Forest Inventory (AFN, 2009) for minor trees assessment, and consisted of a combination of transect sampling (to allow a more effective detection of eucalypt presence) with area surveys (subplots) to measure plant densities. Each sampling site consisted of a $6.78 \mathrm{~m}$ radius circular plot centred on the site coordinates (located using a hand-held GPS - Garmin, e-Trex, Taiwan). Four $5 \mathrm{~m} \times 2 \mathrm{~m}$ transects were established at every site, diverging from the plot centre and oriented towards the north, the south, the east and the west. At the end of each transect, a $1.78 \mathrm{~m}$ radius subplot was established, with its centre 5-m distant from plot centre. Presence of post-fire naturally established E. globulus plants was checked inside the four subplots and along the four transects. In order to distinguish these individuals from pre-fire, artificially sown or planted individuals, we observed cumulatively the following features: absence of charred parts; presence of a conspicuous lignotuber; and location within the plantation inconsistent with spacing. The number of target plants and the height of the median individual were measured in loco inside each of the four subplots. Each individual was assigned to one of the four size classes using a combination of height $(h)$ and diameter at breast height (DBH) - size class 1: $h \leqslant 1.3 \mathrm{~m}$; size class $2: h>1.3 \mathrm{~m}$ and $\mathrm{DBH} \leqslant 5 \mathrm{~cm}$; size class 3 : $h>1.3 \mathrm{~m}$ and $5<\mathrm{DBH} \leqslant 7.5 \mathrm{~cm}$; size $4: h>1.3 \mathrm{~m}$ and DBH $>7.5 \mathrm{~cm}$. At all sampling sites, evidences of several post-fire stand management operations (Table 1) were collected by field observation and, whenever possible, by inquiring land owners. Information about site physiographic position, slope, and aspect was also collected (Table 1). A hypsometer (Haglöf Vertex III, Sweden) was used to measure slope. Aspect was measured using a compass. Additionally, the presence of potential mother trees, either in the plot or in its surroundings (up to $100 \mathrm{~m}$ ), was registered.

\subsection{Data analysis}

Considering that there is no accurate and quick method of determining age of E. globulus plants, we decided to use a broad

Table 1

Description of assessed explanatory variables.

\begin{tabular}{|c|c|c|c|c|}
\hline Variable & Data description & Data type & Data source & Frequency (\%) \\
\hline Pre-fire forest type & Dominant species in the plot & Categorical & $\begin{array}{l}\text { Forest inventory data } \\
\text { and field evidence }\end{array}$ & $\begin{array}{l}\text { P. pinaster }(29.6) \\
\text { E. globulus }(45.8) \\
\text { Mixed }(24.6)\end{array}$ \\
\hline Productivity region & $\begin{array}{l}\text { E. globulus productivity classes, based on } \\
\text { annual precipitation and number of frost days } \\
\text { per year }\end{array}$ & Categorical & $\begin{array}{l}\text { Ribeiro and Tomé } \\
\text { (2000); Tomé et al. } \\
\text { (2001) }\end{array}$ & $\begin{array}{l}\text { High }(35.6) \\
\text { Medium (53.9) } \\
\text { Low }(10.6)\end{array}$ \\
\hline $\begin{array}{l}\text { Post-fire salvage } \\
\text { logging }\end{array}$ & $\begin{array}{l}\text { Cut of Eucalyptus globulus poles and/or Pinus } \\
\text { pinaster trees (all or only dead) }\end{array}$ & Binary $(0 / 1)$ & $\begin{array}{l}\text { Inquiries and field } \\
\text { evidence }\end{array}$ & 69.4 \\
\hline Post-fire tillage & $\begin{array}{l}\text { Mechanical disturbance of the forest floor, by } \\
\text { harrowing, ploughing or ripping }\end{array}$ & Binary (0/1) & $\begin{array}{l}\text { Inquiries and field } \\
\text { evidence }\end{array}$ & 15.8 \\
\hline $\begin{array}{l}\text { Post-fire understorey } \\
\text { removal }\end{array}$ & $\begin{array}{l}\text { Mechanical removal of understorey shrubs and } \\
\text { small trees }\end{array}$ & Binary (0/1) & $\begin{array}{l}\text { Inquiries and field } \\
\text { evidence }\end{array}$ & 16.2 \\
\hline Terrain physiography & Plot physiographic position & Categorical & Field evidence & $\begin{array}{l}\text { Flat or valley } \\
\text { bottom }(10.9) \\
\text { Slope }(78.5) \\
\text { Ridge }(10.6)\end{array}$ \\
\hline Slope & In degrees & Continuous & Field measurement & $\begin{array}{l}{\left[0^{\circ} ; 15^{\circ}\right](50.0)} \\
\left.] 15^{\circ} ; 30^{\circ}\right](44.0) \\
\left.] 30^{\circ} ; 45^{\circ}\right](6.0)\end{array}$ \\
\hline Aspect & $\begin{array}{l}\text { Aspect classes based on Kutiel and Lavee } \\
\text { (1999): unfavourable - SE, S, and SW aspects; } \\
\text { favourable - remaining aspects }\end{array}$ & Categorical & Field evidence & $\begin{array}{l}\text { Unfavourable (31.3) } \\
\text { Favourable (68.7) }\end{array}$ \\
\hline
\end{tabular}


concept of cohort in this study - cohort as a group of individuals of the same species that experienced the same event within the same time interval (Ryder, 1965), using as cohort definer (sensu Schaie (1984)) the natural establishment in a burnt stand. Accordingly, we included all E. globulus plants that had been naturally established within 5-7 years after fire in a single cohort, which was our study subject.

For simplicity purposes, we will refer to post-fire natural establishment of E. globulus as establishment. Similarly, post-fire naturally established E. globulus plants/individuals and post-fire naturally established E. globulus cohort, will be respectively named as plants/individuals and cohort. Nevertheless, the extensive names will be used whenever the use of short names results in ambiguity.

Three response variables were modelled using generalized linear models (GLM): occurrence of establishment (presence/ absence), cohort density (plants $\mathrm{m}^{-2}$ ), and plant median height $(\mathrm{m})$. A plot was considered as having established plants if they occurred in at least one of its transects or subplots. Plant density was estimated by averaging the densities from the different subplots. Median height was also calculated across subplots. Nine explanatory variables were used (Table 1): stand type; tillage; understorey removal; salvage logging; terrain physiography; slope; aspect (based on Kutiel and Lavee (1999)); and E. globulus productivity regions (Fig. 1; adapted from Ribeiro and Tomé (2000) and Tomé et al. (2001)). Productivity region factor was chosen as it could be a surrogate of habitat quality for E. globulus and, consequently, for seedling establishment and growth of this species.

Occurrence of establishment (presence/absence) was modelled by setting a binomial distribution for the response variable and a logit link (occurrence model) (Quinn and Keough, 2002). The cohort density (Fig. 2) was modelled using a gamma distribution and a log link (density model). In this case, only sites with plant establishment were considered. The median heights of established plants had a log normal distribution (Fig. 3), so they were logtransformed and modelled through a Gaussian distribution and an identity link (height model) (Quinn and Keough, 2002). The only three sites with regeneration at subplots located in low productivity regions were discarded in density and height models as these regions were not sufficiently represented. Model selection followed Zuur et al. (2009), starting with a model that included all nine explanatory variables and sequentially removing the variables that did not contribute significantly $(\alpha=0.05)$ to the explained

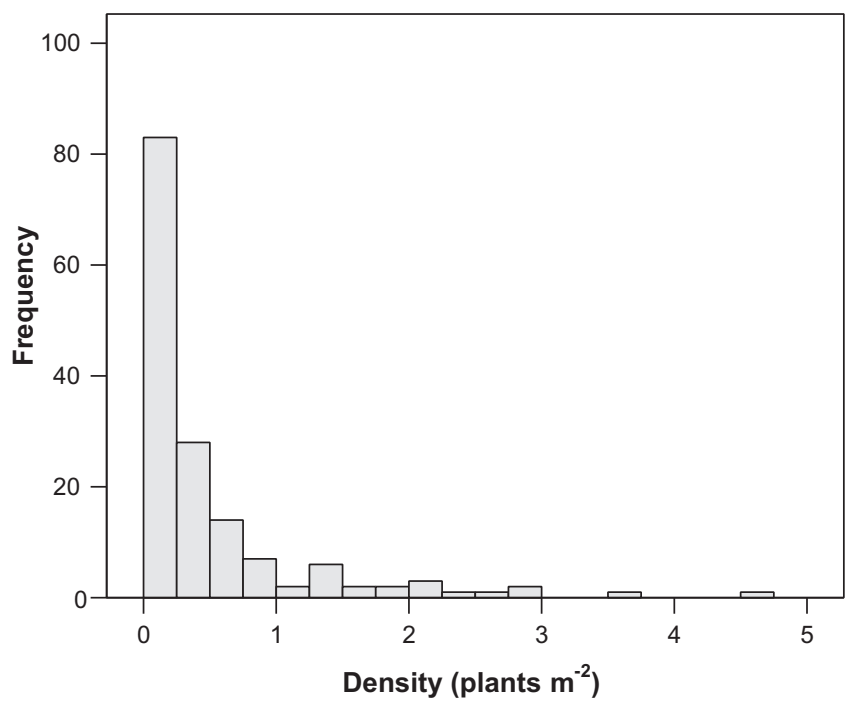

Fig. 2. Observed densities of post-fire naturally established E. globulus cohort, in sampled sites where it was present. $n=153$.

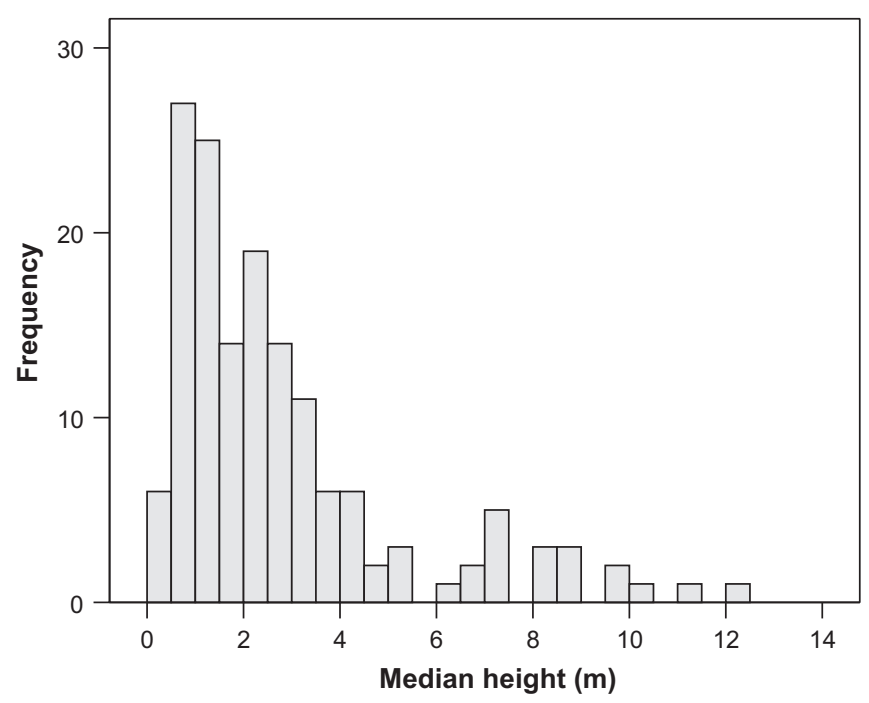

Fig. 3. Median heights of post-fire naturally established E. globulus plants in sampled sites. $n=152$.

deviance (according to analysis of deviance tests). Modelling was performed using R statistical software ( $\mathrm{R}$ Core Team, 2012).

Assessment of each model performance was based on the fraction of total deviance explained by the model. Performance of occurrence model was additionally assessed through the area under the receiver operating characteristics curve, commonly known as area under the ROC curve (AUC) (Pearce and Ferrier, 2000). AUC was estimated using package ROCR for R (Sing et al., 2009). The eventual presence of spatial autocorrelation in the model residuals was tested through a spatial correlogram using the Moran's I autocorrelation coefficient (Fortin and Dale, 2005), employing the function correlog of the ncf package for $\mathrm{R}$ statistical software (Bjornstad, 2009). Significance was tested using 100 permutations and the progressive Bonferroni correction (Legendre and Legendre, 1998).

Relationship between regeneration occurrence and presence of potential mother trees was analysed through a contingency table, $X^{2}$ test, and $\Phi_{2}$ coefficient (Zar, 1996).

Differences on size structure of the naturally established cohort (given by the distribution of individuals into size classes) among sites were assessed, using analysis of similarity (ANOSIM) and non-metric multidimensional scaling (MDS) (Clarke, 1993). Data on distribution of individuals among sizes classes in different sites were standardized. Then, a similarity matrix of those frequencies was computed using the Bray-Curtis coefficient of similarity (Bray and Curtis, 1957; Clarke, 1993). MDS was performed with 20 restarts and a two-dimension MDS diagram was built. A one-way ANOSIM test was performed for each factor separately. Then, obtained global $R$ value was compared with the $R$ probability distribution, previously produced with a maximum of 9999 random permutations, considering $\alpha=0.05$. ANOSIM and MDS were performed using software Primer 5 for Windows (version 5.2.9) (Primer-e, 2002).

\section{Results}

The 284 sites were unevenly distributed among different stand types, productivity regions and topographic conditions (Table 1).

Post-fire management occurred in $78.5 \%$ of sites. Salvage logging was the most common operation (69.4\%), while understorey removal (16.2\%) and tillage (15.8\%) were less common (Table 1$)$.

A total of 3062 naturally established E. globulus plants were observed across $72.5 \%$ of the 284 sampling sites. Almost every site 
(99.5\%) with natural regeneration had or had had potential mother trees inside the plot or nearby. At sites with no regeneration, these seed trees were, or had been present in $29.5 \%$ of cases. This difference was significant $\left(\varphi^{2}=0.79, p<0.001\right)$. At the sites where studied plants were present at the subplots, cohort density had its median at 0.20 plants $\mathrm{m}^{-2}$ and its maximum at 4.55 plants $\mathrm{m}^{-2}$ (mean $\pm \mathrm{SD}=0.48 \pm 0.73$ plants $\mathrm{m}^{-2}$ ). Plant median height was $2.0 \mathrm{~m}$, and the values ranged from 0.2 to $12.1 \mathrm{~m}$ (mean $\pm \mathrm{SD}$ was $2.7 \pm 2.4 \mathrm{~m}$ ). These two variables had positively skewed distributions (Figs. 2 and 3 ).

The occurrence model showed that establishment was significantly influenced by stand type, productivity region, and understorey removal, together explaining $56.8 \%$ of the deviance (Table 2). AUC value for occurrence model was 0.941, revealing its high accuracy (Swets, 1988). Establishment probability was higher in mixed and pure E. globulus stands, in medium and high productivity regions, and when understorey vegetation was not removed, although this latter effect was less important and appeared to be overshadowed by other factors (Fig. 4(a)). The main explanatory variables in the density model were productivity region and two post-fire management operations, although altogether they only explained $11.6 \%$ of the deviance (Table 2). Density was higher in the high productivity region, and when salvage logging had occurred, while it was lower following tillage (Fig. 4(b)). According to height model, plants were taller in the high productivity region and smaller where the soils were tilled (Fig. 4(c)). However, this model only explained $8.0 \%$ of the deviance (Table 2 ). There was no significant spatial autocorrelation pattern in any of the models' residuals.

The MDS analysis performed to compare the size structure of the spontaneous cohort among different sites had a stress of 0.03 , revealing an excellent representation with no prospect of misinterpretation (Clarke, 1993). The 2-dimension MDS diagram (Fig. 5) showed two main groups of sites: one group of 52 sites lacking plants of size 1 , located along the vertical axis (group A); and another group of 119 sites lacking of sizes 3 and 4 , located along the horizontal axis (group B). The two groups partially overlapped. This overlap involved 38 sites that only had plants of size 2 . The far end of group $B$ comprised sites only with plants of size 1 ( $C$; $n=23$ ). In between groups $A$ and $B$, there were sites with different proportions of plants belonging to several size classes $(1,2$, and 3 or/and 4). Size classes 1 and 2 were prevalent in the study, 95.4\%

\section{Table 2}

Generalized linear models for natural establishment of E. globulus - occurrence likelihood, cohort density, and plant median height. For each response variable, explanatory variables kept in the respective final model are indicated through their coefficient $\pm \mathrm{SE}$, as well as their significance $\left({ }^{* * *} p<0.001,{ }^{* *} p<0.01,{ }^{*} p<0.05\right)$.

\begin{tabular}{llll}
\hline & Occurrence & Density & Height \\
\hline Intercept & $1.002 \pm 0.925$ & $-0.812 \pm 0.260^{*}$ & $0.889 \pm 0.113^{* * *}$ \\
Stand type & $-{ }^{* * *}$ & & \\
$\quad$ E. globulus & 0 & & \\
$\quad \begin{array}{l}P \text { p pinaster } \\
\quad \text { Mixed }\end{array}$ & $-4.000 \pm 0.521$ & & \\
$\quad 1.717 \pm 1.073$ & & $-^{*}$ \\
Productivity region & $-^{* *}$ & $-^{*}$ & 0 \\
$\quad$ High & $1.732 \pm 0.900$ & 0 & $-0.293 \pm 0.146$ \\
$\quad$ Medium & $2.299 \pm 0.877$ & $-0.501 \pm 0.259$ & - \\
$\quad$ Low & 0 & - & \\
Salvage logging & & $0.597 \pm 0.278^{*}$ & \\
Tillage & & $-0.864 \pm 0.333^{*}$ & $-0.436 \pm 0.193^{*}$ \\
Understorey removal & $-1.462 \pm 0.624^{*}$ & & \\
\hline$n$ & 284 & 150 & 149 \\
Explained deviance & $56.8 \%$ & $11.6 \%$ & $8.0 \%$ \\
AUC & 0.941 & & \\
\hline
\end{tabular}

of plants belonged to one of these classes, and they were present in all sites that had natural regeneration at the subplots. Size classes 3 and 4 were the rarest, together they occurred in $20.6 \%$ of sites which had natural regeneration at subplots (all but group B) and they represented only $4.5 \%$ of plants. ANOSIM showed that tillage was the only explanatory variable that significantly affected cohort size structure $(p=0.048)$ but its influence on relative abundances of different size classes was not very strong (global $R=0.064$ ). Plants of sizes 3 and 4 were absent in tilled sites (Fig. 5).

\section{Discussion}

Considering the wide geographical range of the survey, the diversity of sampled stands and the relatively small size of the sampling plots, it is relevant that $72.0 \%$ of plots from all stands had naturally established E. globulus plants. The positive association between the occurrence of these plants and the presence of potential mother trees suggested the existence of a widespread establishment in burnt stands where close seed sources were available. The occurrence of progeny restricted to vicinity of these trees is in accordance with the limited dispersal capacity of the species (Cremer, 1977) and occasional occurrence of regeneration some tens of meters away from these trees are compatible with results obtained by Larcombe et al. (2013) and Calviño-Cancela and Rubido-Bará (2013).

The occurrence model revealed high accuracy in predicting the likelihood of establishment, pointing at stand type, productivity region, and understorey removal as main explanatory variables.

Natural establishment was very common in pure E. globulus stands (90.9\%) and mixed stands (94.9\%), while it only existed in $19.1 \%$ of pure $P$. pinaster stands. This difference was very significantly reflected in the occurrence model. While this result is not surprising, since the presence of adult E. globulus trees (seed sources) naturally increases the likelihood of recruitment, it is noticeable that this type of establishment also occurred often in pure $P$. pinaster stands. However, all but one of concerned sites had adult E. globulus trees or its burnt remnants within the plot or had conspicuous potential mother trees in the surrounding area. The presence of sexually mature E. globulus trees in pure $P$. pinaster stands is common in Portugal (Godinho-Ferreira et al., 2005).

Likelihood of establishment was higher in better productivity regions, based on classification proposed by Ribeiro and Tomé (2000). The criteria used in this classification to define homogeneous climatic regions for E. globulus productivity ( growth) were essentially based on indicators of water availability and frost occurrence. These factors are known to affect not only E. globulus growth, but also this species recruitment, establishment, and survival. In fact, water deficit negatively affects: E. globulus seed germination (López et al., 2000; Humara et al., 2002); E. globulus seedling establishment success (González-Muñoz et al., 2011); and summer survival of young eucalypts (Jacobs, 1955; Whelam and Main, 1979; Wellington and Noble, 1985a; Stoneman et al., 1994; Richards and Lamont, 1996). Additionally, frost may directly kill foliage and buds and sometimes the whole plant (Cremer et al., 1984). T50 for E. globulus seedlings leaves is $-5.5^{\circ} \mathrm{C}$ (Almeida et al., 1994). These facts may explain why higher productivity regions are more likely to have E. globulus establishment. Results obtained by Larcombe et al. (2013) point at the same direction, since they found that sites where precipitation seasonality was lower had higher probability to have natural establishment of this species, in Australia, similarly to what happens in areas corresponding to higher productivity regions in Portugal, probably due to reduced water stress in late summer.

Most of the surveyed sites (68.3\%) did not show any evidences of management activities, except for salvage logging. Establishment 


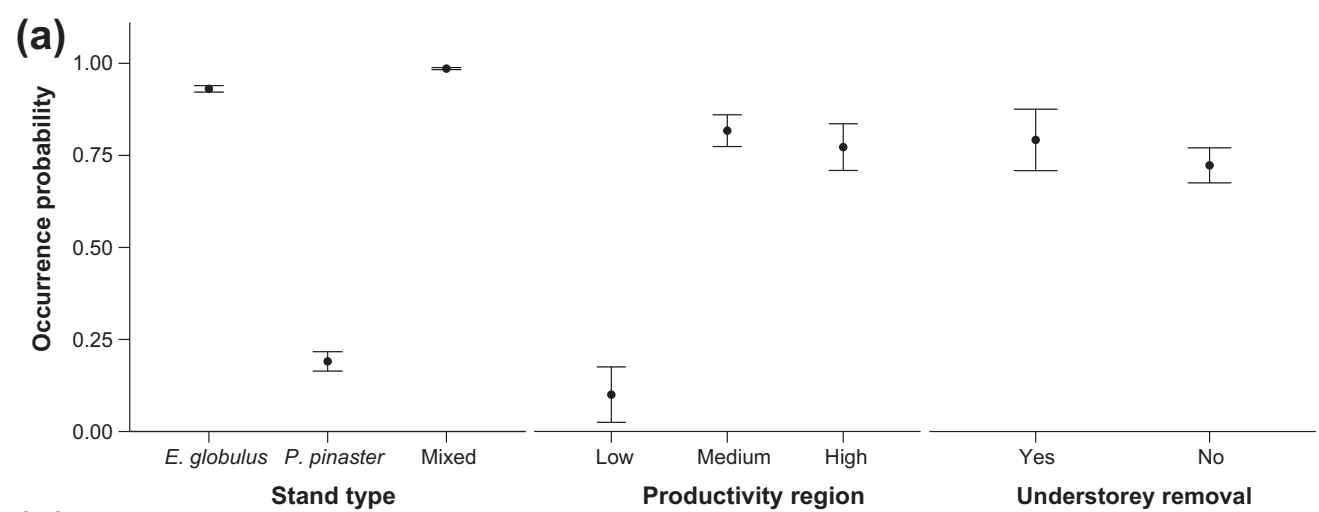

(b)
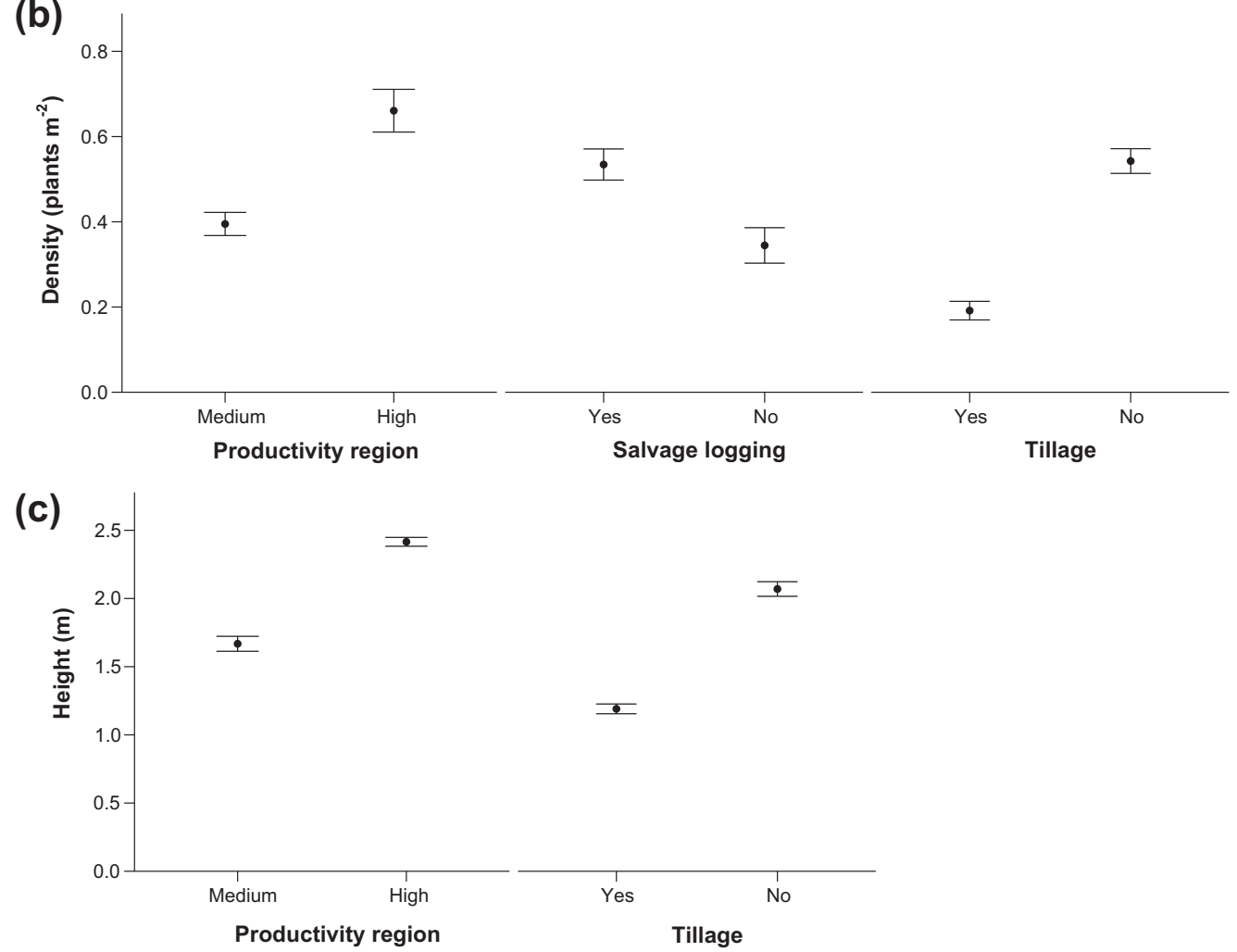

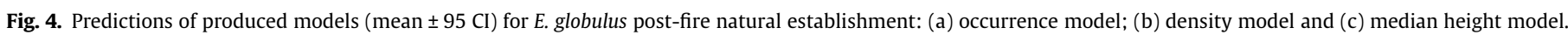

occurred in all but one of those "unmanaged" sites in pure E. globulus stands, and the same happened in mixed stands, while only $15.8 \%$ of "unmanaged" pure $P$. pinaster sites had spontaneous E. globulus plants. This suggests that poor management or total lack of it favoured establishment both in pure E. globulus stands and in mixed stands; while other factors may have major influence on the phenomenon in pure $P$. pinaster stands. However, a more detailed analysis shows that different management operations had different effects.

Sites where understorey removal had occurred were less likely to have naturally established $E$. globulus plants, although this effect was minor. This operation is aimed at destroying understorey vegetation, which may include small E. globulus individuals. In some sites where understorey was removed, probably all previously recruited E. globulus seedlings/saplings were killed and no subsequent establishment succeeded, resulting in absence of plants at sampling time. This would be compatible with the idea that most post-fire establishment happens shortly after fire (Pryor, 1976; Florence, 1996).
Densities of naturally established E. globulus cohort observed in our study were not easy to compare with other quantitative references on this subject because of differences in methodology and considered factors (Virtue and Melland, 2003; Calviño-Cancela and Rubido-Bará, 2013; Larcombe et al., 2013). In order to compare our data to those from other studies, we needed to consider only pure E. globulus stands. Densities observed in our study (maximum $=4.55$ plants $\mathrm{m}^{-2}$; mean $=0.48$ plants $\mathrm{m}^{-2}$ ) were largely higher than those registered by Larcombe et al. (2013) (maximum $=1.98 \times 10^{-3}$ plants $\mathrm{m}^{-2} ; \quad$ mean $=8.52 \times 10^{-4}$ plants $\mathrm{m}^{-2}$ ) within $10 \mathrm{~m}$ from plantation borders, including both burnt and unburnt areas. Meanwhile, the absolute values of maximum density mentioned in the other two references had the same order of magnitude that we observed: $1-2$ plants $\mathrm{m}^{-2}$ (Virtue and Melland, 2003) and about 2 plants $\mathrm{m}^{-2}$ (Calviño-Cancela and Rubido-Bará, 2013), both located next to unburnt plantations edges. However, we cannot evaluate if these values are lower or higher than ours because they might result from potential periods of recruitment with very different time lengths. 


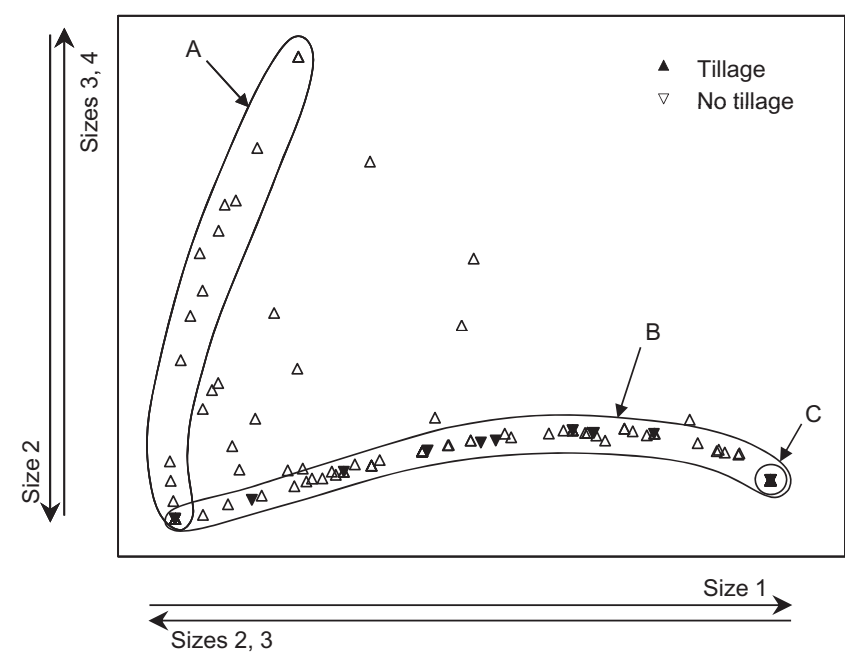

Fig. 5. Ordination diagram of size structure of post-fire naturally established $E$. globulus cohort in sampled sites, obtained from a non-metric multidimensional scaling analysis. Size classes of plants: size 1 - height $\leqslant 1.3 \mathrm{~m}$; size 2 height $>1.3 \mathrm{~m}$ and $\mathrm{DBH} \leqslant 5 \mathrm{~cm}$; size 3 - height $>1.3 \mathrm{~m}$ and $5<\mathrm{DBH} \leqslant 7.5 \mathrm{~cm}$. $n=153$.

The density model pointed at productivity region and two management operations as the most important studied variables for explaining young cohort density.

Like occurrence, cohort density was higher in the most productive region. Since water deficit can negatively affect eucalypt recruitment, establishment and survival, as discussed before, it may explain this density difference. Our results on density also agreed with those reported by Larcombe et al. (2013) for Australia, with respect to annual precipitation and precipitation seasonality.

Salvage logging had a positive effect on cohort density. Although logging can destroy post-fire established plants (McIver and Starr, 2000), it is not likely because it is recommended to harvest burnt E. globulus trees shortly after fire (Shakesby et al., 1996). In fact, logging has been associated with plant recruitment in $E$. globulus stands and in other eucalypt stands (Skolmen and Ledig, 1990; Fagg, 2001), since seedlings may originate from the so-called "slash seed" (Fagg, 2001), which in the specific case of salvage logging may be enhanced by the seed shed caused by fire (Cremer, 1965). Additionally, reduction of competition caused by salvage logging might have improved establishment success of youngsters, resulting in higher densities of their cohort in fallen stands. Eucalypts are not able to become established and develop normally under a complete overstorey canopy (Florence, 1996). E. globulus usually regenerates only when the overstorey is removed (Stoneman, 1994). Asymmetrical competition was observed in E. globulus by Tomé et al. (1994). Several Australian studies under temperate and Mediterranean climates have shown that water deficits are stronger in eucalypt seedlings in sites with overstorey than in sites where it did not exist, resulting in higher mortality rates in the former (Bowman and Kirkpatrick, 1986; Battaglia and Wilson, 1990; Stoneman et al., 1994). Negative effects of water stress on E. globulus recruitment and establishment were already discussed.

Tillage had a negative effect on cohort density. This operation can destroy post-fire regeneration from seeds (Catry et al., 2010). Direct killing of most of naturally established E. globulus plants was probably the major cause of low density of their cohort in tilled sites. Harrowing reduces the development of understorey biomass in E. globulus plantations (Carneiro et al., 2008) and this may be related to a reduction of nutrients in soil caused by tillage (Madeira et al., 1989; Carneiro et al., 2008). Increased soil erosion due to tillage probably resulted in harsher soil conditions that might have hindered plant establishment (Shakesby et al., 1996) and increased mortality since then, contributing to an even lower density of the cohort in those sites.

Median height of spontaneous E. globulus plants in surveyed plots had a broad variation across sites $(0.2-12.1 \mathrm{~m})$. This fact could be related either with different times of recruitment or with differences among the sites where these plants were growing. As $E$. globulus age is difficult to determine (Williams and Brooker, 1997; Leal et al., 2004), the relationship between size and age of observed plants is partially speculative. Even so, plant size can be used for demographic interpretations in eucalypt communities (Florence, 1996). Therefore, the existence of continuous recruitment or occurrence of several recruitment episodes might explain the diversity of plant sizes observed in many sites and especially the abundance of smaller plants. Nevertheless, according to literature, it is probable that most of these plants have been recruited in the first year after fire, since: fire improves conditions for eucalypt recruitment (Cremer, 1965; Kirkpatrick, 1975; O'Dowd and Gill, 1984; Chambers and Attiwill, 1994; Stoneman, 1994; Gill, 1997); eucalypt seeds are short lived in soil (Jacobs, 1955; Cremer et al., 1984; Wellington and Noble, 1985b) and germinate as soon as they have favourable conditions to do so in nature (Penfold and Willis, 1961); and E. globulus plants take 4-7 years to produce their first seeds (Kirkpatrick, 1975; Turnbull and Pryor, 1984; Jordan et al., 1999) and 7 years to produce seeds after canopy burn (Kirkpatrick, 1975).

More than $95 \%$ of sampled individuals were of sizes 1 or 2 , and were at most $6.77 \mathrm{~m}$ tall (height estimate based in Marques et al. (2011)). If we presume a major event of recruitment in the first year after fire, these plants were shorter than it would be expected (data from WebGlobulus 2.1 simulator (Palma, 2009)). Additionally, they were also much shorter than the resprouts of most of the coexisting burnt trees. Therefore, we may think about the former as dominated, suppressed or growth restricted trees (Skolmen and Ledig, 1990; Florence, 1996). Eucalypt lignotuberous seedlings/saplings are very resistant, therefore they can survive for long years in the understorey, and may be considered as a 'regeneration pool' in eucalypt forests (Florence, 1996; Ashton, 2000), since they can speed up growth after release from overstorey competition (Florence, 1996). If we consider the observed persistence of growth restricted E. globulus trees, their latent growth capacity, and their ability to attain reproductive state (pers. observ.); we may say that conditions might exist for natural perpetuation of this species in many surveyed sites. This means that the naturalization process (sensu Richardson et al. (2000)) is undergoing.

Plants with the above features are often used in forestry as advance growth (Jacobs, 1955; Florence, 1996; Alves et al., 2012), being a most important aspect of eucalypt forest regeneration cycle in Australia (Ashton, 2000). Although this practice is possible with E. globulus in Portugal, the species invasive potential in this territory (Marchante et al., 2008; Silva and Marchante, 2012) must be taken into account.

The height model indicated that productivity region and tillage were significant explanatory variables. Tillage also affected the size structure of the regenerating population. However, other nonstudied variables might have significantly influenced the observed plant height.

Plants were taller in the highest productivity region. Climate factors (frost and water availability) that influence E. globulus growth, and consequently height, are the basis of this classification. Negative effect of water stress on E. globulus growth is broadly known (Wang et al., 1988; Tomé et al., 1994; Osório et al., 1998; Pita and Pardos, 2001; Humara et al., 2002). Actually, lack of water is the main limiting factor to E. globulus growth in Mediterranean type ecosystems (Alves et al., 2012), even though this species can 
deal with more severe water stress in Portugal and Spain than in its native range (Turnbull and Pryor, 1984; Alves et al., 2012). Cold is also an important limiting factor to E. globulus growth. Temperatures around $0 \pm 2{ }^{\circ} \mathrm{C}$ inhibit water uptake and growth of $E$. globulus seedlings (Almeida et al., 1994; Costa-e-Silva et al., 2008). Our results on relative height of plants among productivity regions were obviously consistent with the rationale underlying classification produced by Ribeiro and Tomé (2000). They also coincide with the trends predicted by model Globulus 2.1 (Tomé et al., 2001).

Tillage had a negative effect on median height of plants. Wherever performed, this management operation also slightly affected the size structure of the cohort; it completely eliminated plants of sizes 3 and 4 and tended to favour the presence of size 1 plants. If we admit the existence of recruitment along time, since fire until sampling, many of the observed smaller plants might have established after tillage, while all or part of pre-existing plants was destroyed by tillage, both contributing to reduced median height of plants at sampling time at tilled sites. Tillage reduces nutrient availability in soil (Madeira et al., 1989). The synergetic effects of fire and tillage risk aggravating erosion even more (Coelho et al., 1995; Shakesby et al., 1996). Carneiro et al. (2008), found that harrowing reduced understorey development in E. globulus plantations and related it with reduction of nutrients in soil. The indirect effect of tillage hampering plant growth can be an additional explanation for lower plant median height at tilled sites.

Aspect, slope and topographic position influence incident solar radiation, water flow and soil erosion; whose effects on temperature, radiation, water and nutrients availability to plants may be determinants of their successful establishment and development (Jacobs, 1955; Moore et al., 1988; Shakesby et al., 1996; Kutiel and Lavee, 1999; Taiz and Zeiger, 2002; Pereira, 2007). Notably, none of topographical explaining variables was considered significant in any of the analyses. Similarly, Larcombe et al. (2013) found no significant influence of slope and aspect either on occurrence of natural establishment of E. globulus or on its density. This probably means that potential effects of topography on our response variables were overwhelmed by other factors effects, or even hidden by background noise of data.

The built models did not explain all the observed variability. Some other factors, like fire severity and intensity, might have affected observed establishment (Mount, 1969; Pryor, 1976; Florence, 1996; Gill, 1997; Martínez et al., 2002; Bailey et al., 2012), but they were not considered in this study because accurate evaluation of these features is not feasible 5-7 years after fire, when the study was done.

\section{Conclusions}

This study showed that the natural establishment of E. globulus was widespread in two types of burnt stands (pure E. globulus and mixed) and that this establishment was favoured by climatic conditions that enhance the productivity of this species. Considering the frequency of occurrence and the characteristics (presumable age, size, lignotuber) of observed plants, we can say that conditions for natural persistence of E. globulus were probably met in those types of stands in the studied regions. However, further studies are needed to assess the capacity that this type of plants has to complete the life cycle under the conditions they are growing at, in order to better understand the naturalization process of this species in Portuguese territory.

The use of a naturally regenerating cohort as advance growth for production purposes seems possible. Nevertheless, whenever this possibility is considered, the fact that E. globulus is an exotic species with some invasive potential in Portugal must be kept in mind.
On the other hand, the increased stand density that results from the existence of spontaneously established plants may have detrimental consequences in terms of forest management and may lead to a higher fire hazard. Attention should be paid to the very high prevalence of these plants in two of the studied stand types, regarding the wide distribution of E. globulus and the high incidence of forest fires in Portugal. Our results suggested that both the lack and the type of post-fire management operations strongly influenced seminal regeneration of $E$. globulus in burnt stands. Tillage has detrimental effects on this regeneration and may be considered in management programs for its control, in the geographical range of this study.

Mechanisms responsible for this species establishment are still poorly understood. It is not clear yet if post-fire recruitment of plants occurs mainly in a single initial recruitment event or in successive minor events or even if it is continuous along time. Comparative studies on this subject, either in burnt and unburnt areas, are needed to clarify the role of fire on this species recruitment and establishment. For instance: effects of fire severity and intensity on natural regeneration of the species are still unknown; and there is no quantitative evidence on the importance of firestimulated seed shed and how it interacts with post-fire management. Considering the wide expansion of E. globulus in the world, the study of such mechanisms is undoubtedly a fertile field for future research initiatives.

\section{Acknowledgements}

This research was funded by Fundação para a Ciência e a Tecnologia (FCT) in the frame of project "FireReg" (PTDC/AGRCFL/ 099420/2008). Ana Águas has a PhD scholarship from FCT (SFRH/ $\mathrm{BD} / 76899 / 2011)$. We thank the forest owners associations that helped us locate the plots in the field and providing information on post-fire management, in particular AFLOMAÇÃO. We also express our gratitude to all who helped collect data during field work, namely Mariana Pedro, Lia Dinis, Carlos Fernandes and Irina Oliveira. We finally thank the reviewers for their valuable comments.

\section{References}

AFN, 2009. Instruções para o Trabalho de Campo do Inventário Florestal Nacional IFN 2005/2006. Autoridade Florestal Nacional, Lisbon.

AFN, 2010. Relatório Final do 5ํInventário Florestal Nacional. Autoridade Florestal Nacional, Lisbon.

Almeida, J.D., Freitas, H., 2006. Exotic flora of continental Portugal - a reassesment. Botanica Complutensis 30, 117-130.

Almeida, M.H., Chaves, M.M., Silva, J.C., 1994. Cold acclimation in eucalypt hybrids, Tree Phys. 14, 921-932.

Alves, A.M., Pereira, J.S., Correia, A.V., 2012. Silvicultura - A Gestão dos Ecossistemas Florestais. Fundação Calouste Gulbenkian, Lisbon.

Anderson, R.C., Brown, L.E., 1980. Influence of a prescribed burn on colonizing black locust. In: Garrett, H.E.C., G.S., (Ed.), Proc. Central Hardwood Forest Conference III. University MO, Columbus, pp. 330-336.

Andreu, J., Vila, M., Hulme, P.E., 2009. An assessment of stakeholder perceptions and management of noxious alien plants in Spain. Environ. Manage. 43, 1244-1255.

Arianoutsou, M., Vilà, M., 2012. Fire and invasive plant species in the Mediterranean basin. Israel J. Ecol. Evol. 58, 195-203.

Ashton, D., 1981. Fire in tall open-forests (wet sclerophyll forests). In: Gill, A.M., Groves, R.H., Noble, I.R. (Eds.), Fire and the Australian Biota. The Australian Academy of Science, Camberra, pp. 339-366.

Ashton, D.H., 2000. Ecology of eucalypt regeneration. In: Keane, P.J., Kile, G.A., Podger, F.D., Brown, B.N. (Eds.), Diseases and Pathogens of Eucalypts. CSIRO, Collingwood, pp. 47-60.

Bailey, T.G., Davidson, N.J., Close, D.C., 2012. Understanding the regeneration niche: microsite attributes and recruitment of eucalypts in dry forests. Forest Ecol. Manage. 269, 229-238.

Battaglia, M., Wilson, L.P. 1990. Effect of shelterwoods on stocking and growth of regeneration in dry high altitude Eucalyptus delegatensis forests. Aust. Forest. 53, 259-265.

Bjornstad, O.N., 2009. ncf: spatial nonparametric covariance functions. R package version $1.1-3$

Bowman, D.M.J.S., Kirkpatrick, J.B., 1986. Establishment, suppression and growth of Eucalyptus delegatensis R.T. Baker in multiaged forests. III. Intraspecific 
allelopathy, competition between adult and juvenile for moisture and nutrients, and frost damage to seedlings. Aust. J. Botany 34, 81-94.

Bray, J.R., Curtis, J.T., 1957. An ordination of the upland forest communities of southern Wisconsin. Ecol. Monographs 27, 325-349.

Calviño-Cancela, M., Rubido-Bará, M., 2013. Invasive potential of Eucalyptus globulus: seed dispersal, seedling recruitment and survival in habitats surrounding plantations. Forest Ecol. Manage. 305, 129-137.

Carneiro, M., Fabião, A., Martins, M., Fabião, A., Abrantes da Silva, M., Hilário, L. Lousã, M., Madeira, M., 2008. Effects of harrowing and fertilisation on understory vegetation and timber production of a Eucalyptus globulus Labill. plantation in Central Portugal. Forest Ecol. Manage. 255, 591-597.

Catry, F.X., Bugalho, M., Silva, J.S., Fernandes, P., 2010. Gestão da vegetação pós-fogo In: Moreira, F., Catry, F.X., Silva, J.S., Rego, F. (Eds.), Ecologia do Fogo e Gestão de Áreas Ardidas. ISAPress, Lisbon.

Chambers, D.P., Attiwill, P.M., 1994. The ash-bed effect in Eucalyptus regnans forest: chemical, physical and microbiological changes in soil after heating or partia sterilisation. Aust. J. Botany 42, 739-749.

Clarke, K.R., 1993. Non-parametric multivariate analyses of changes in community structure. Aust. J. Ecol. 18, 117-143.

Coelho, C.O.A., Shakesby, R.A., Walsh, R.P.D., 1995. Effects of forest fires and postfire land management practice on soil erosion and stream dynamics, Águeda basin, Portugal, Soil and groundwater research report V. In, Environment and quality of life. European Commission, Office for Official Publications of the European Communities, Luxembourg.

Costa-e-Silva, F., Shvaleva, A., Broetto, F., Ortuñuo, M.F., Rodrigues, M.L., Almeida, M.H., Chaves, M.M., Pereira, J.S., 2008. Acclimation to short-term low temperatures in two Eucalyptus globulus clones with contrasting drought resistance. Tree Physiol. 29, 77-86.

Cremer, K.W., 1965. Effects of fire of seedshed from Eucalyptus regnans. Aust. Forestry 29, 252-262.

Cremer, K.W., 1977. Distance of seed dispersal in eucalypts estimated from seed weights. Aust. Forest Res. 7, 225-228.

Cremer, K.W., Cromer, R.N., Florence, R.G., 1984. Stand establishment. In: Hillis, W.E., Brown, A.G. (Eds.), Eucalypts for Wood Production. CSIRO Academic Press, Melbourne, pp. 82-135.

DGRF, 2007. Estratégia Nacional para as Florestas. Imprensa Nacional-Casa da Moeda, Lisbon.

Fagg, P.C., 2001. Eucalypt Sowing and Seedfall. Native Forest Silviculture Guideline no. 8. Department of Natural Resources and Environment, Victoria, Melbourne.

FAO, 2010. Global forest resources assessment 2010. In: FAO Forestry Paper. Food and Agriculture Organization of the United Nations, Rome, pp. 340.

Fernandes, P.M., Loureiro, C., Palheiro, P., Vale-Gonçalves, H., Fernandes, M.M., Cruz M.G., 2011. Fuels and fire hazard in blue gum (Eucalyptus globulus) stands in Portugal. Boletín del CIDEU, 53-61.

Florence, R.G., 1996. Ecology and Silviculture of Eucalypt Forests. CSIRO, Collingwood.

Fortin, M.-J., Dale, M.R.M.R.T., 2005. Spatial Analysis: A Guide for Ecologists. Cambridge University Press, Cambridge.

Gassó, N., Basnou, C., Vilà, M., 2010. Predicting plant invaders in the Mediterranean through a weed risk assessment system. Biol. Invasions 12, 463-476.

Gill, A.M., 1997. Eucalypts and fires: interdependent or independent? In: Williams, J.E., Woinarski, J.C.Z. (Eds.), Eucalypt Ecology: Individuals to Ecosystems. Cambridge University Press, Cambridge, pp. 151-167.

Godinho-Ferreira, P., Azevedo, A., Rego, F., 2005. Carta da tipologia florestal de Portugal Continental. Silva Lusitana 13, 1-34.

González-Muñoz, N., Castro-Díez, P., Fierro-Brunnenmeister, N., 2011 Establishment success of coexisting native and exotic trees under an experimental gradient of irradiance and soil moisture. Environ. Manage. 48 764-773.

Gordon, D.R., Flory, S.L., Cooper, A.L., Morris, S.K., 2012. Assessing the invasion risk of Eucalyptus in the United States using the Australian weed risk assessment. Int. J. Forest. Res. 2012, 1-7.

Humara, J.M., Casares, A., Majada, J., 2002. Effect of seed size and growing media water availability on early seedling growth in Eucalyptus globulus. Forest Ecol. Manage. 167, 1-11.

ICNF, 2013. IFN6 - Áreas dos usos do solo e das espécies florestais de Portugal Continental. Resultados preliminares. In: Instituto da Conservação da Natureza e das Florestas, Lisbon, pp. 33.

Jacobs, M.R., 1955. Growth Habits of the Eucalypts. Forest and Timber Bureau, Canberra.

Jordan, G.J., Potts, B.M., Wiltshire, R.J.E., 1999. Strong, independent, quantitative genetic control of the timing of vegetative phase change and first flowering in Eucalyptus globulus ssp. globulus (Tasmanian blue gum). Heredity 83, 179-187.

JRC, 2012. Forest fires in Europe Middle East and North Africa 2011. In: Joint Research Centre Sientific and Technical Reports. Joint Research Centre, Ispra, p. 108.

Kirkpatrick, J.B., 1975. Natural distribution of Eucalyptus globulus Labill. Aust Geograph. 13, 22-35.

Kutiel, P., Lavee, H., 1999. Effect of slope aspect on soil and vegetation properties along an aridity transect. Israel J. Plant Sci. 47, 169-178.

Larcombe, M., Silva, J.S., Vaillancourt, R., Potts, B., 2013. Assessing the invasive potential of Eucalyptus globulus in Australia: quantification of wildling establishment from plantations. Biol. Invasions, 1-19.

Leal, S., Pereira, H., Grabnerz, M., Wimmert, R., 2004. Tree-ring structure and climatic effects in young Eucalyptus globulus Labill. grown at two Portuguese sites: preliminary results. Dendrochronologia 21, 139-146.
Legendre, P., Legendre, L., 1998. Numerical Ecology. Elsevier, Amsterdam.

López, M., Humara, J.M., Casares, A., Majada, J., 2000. The effect of temperature and water stress on laboratory germination of Eucalyptus globulus Labill. seeds of different sizes. Annal. Forest Sci. 57, 245-250.

Madeira, M., Melo, M., Alexandre, C., Steen, E., 1989. Effects of deep ploughing and superficial disc harrowing on physical and chemical soil properties and biomass in a new plantation of Eucalyptus globulus. Soil Tillage Res. 14, 163-175.

Mandle, L., Bufford, J., Schmidt, I., Daehler, C., 2011. Woody exotic plant invasions and fire: reciprocal impacts and consequences for native ecosystems. Biol. Invasions 13, 1815-1827.

Marchante, E., Freitas, H., Marchante, H., 2008. Guia Prático para a Identificação de Plantas Invasoras de Portugal Continental. Imprensa da Universidade de Coimbra, Coimbra.

Marques, S., Borges, J.G., Garcia-Gonzalo, J., Moreira, F., Carreiras, J.M.B., Oliveira, M., Cantarinha, A., Botequim, B., Pereira, J.M.C., 2011. Characterization of wildfires in Portugal. Euro. J. Forest Res. 130, 775-784.

Martínez, E., Madrigal, J., Hernando, C., Guijarro, M., Vega, J., Pérez-Gorostiaga, P., Fonturbel, M., Cuiñas, P., Alonso, M., Beloso, M., 2002. Effect of fire intensity on seed dispersal and early regeneration in a Pinus pinaster forest. In: Viegas, D.X. (Ed.), Forest Fire Research and Wildland Fire Safety: IV International Conference on Forest Fire Research 2002. Wildland Fire Safety Summit, Luso, Coimbra.

McIver, J.D., Starr, L.L., 2000. Environmental effects of post-fire logging: literature review and annotated bibliography. In: General Technical Report. United States Department of Agriculture, Forest Service, Pacific Northwest Research Station, Portland.

MCPFE, 2007. State of Europe's Forests 2007 - the MCPFE report on sustainable forest management in Europe. In: Ministerial Conference on the Protection of Forests in Europe. UNECE, FAO, Warsaw.

Moore, I., O'Loughlin, E., Burch, G., 1988. A contour-based topographic model for hydrological and ecological applications. Earth Surf. Proc. Landforms 13, 305320.

Moreira, F., Vaz, P., Catry, F., Silva, J.S., 2009. Regional variations in wildfire preference for land cover types in Portugal: implications for landscape management to minimize fire hazard. Int. J. Wildland Fire 18, 563-574.

Mount, A., 1964. The interdependence of the eucalypts and forest fires in southern Australia. Aust. Forest. 28, 166-172.

Mount, A., 1969. Eucalypt ecology as related to fire. In: Proceedings of Tall Timbers Fire Ecolology Conference, pp. 75-108.

Nunes, M.C.S., Vasconcelos, M.J., Pereira, J.M.C., Dasgupta, N., Alldredge, R.J., 2005. Land cover type and fire in Portugal: do fires burn land cover selectively? Landscape Ecol. 20, 661-673.

O’Dowd, D.J., Gill, A.M., 1984. Predator satiation and site alteration following fire: mass reproduction of alpine ash (Eucalyptus delegatensis) in southeastern Australia. Ecology 64, 1052-1066.

Osório, J., Osório, M., Chaves, M., Pereira, J., 1998. Water deficits are more important in delaying growth than in changing patterns of carbon allocation in Eucalyptus globulus. Tree Physiol. 18, 363-373.

Palma, J.H.N., 2009. WebGlobulus 2.1: a web-based interface to project Eucalyptus globulus stands in Portugal. In: <http://home.isa.utl.pt/ joaopalma/modelos/ globulus $>$ (retrieved in 10.10.13)

Pearce, J., Ferrier, S., 2000. Evaluating the predictive performance of habitat models developed using logistic regression. Ecol. Model. 133, 225-245.

Penfold, A.R., Willis, J.L., 1961. The Eucalypts - Botany, Cultivation, Chemistry and Utilization. Leonard Hill [Books] Limited, London.

Pereira, J.S., 2007. Uma espécie altamente produtiva. In: Silva, J.S. (Ed.), Pinhais e Eucaliptais, a Eloresta Cultivada. Público, FLAD, LPN, Lisbon, pp. 167-183.

Pita, P., Pardos, J.A., 2001. Growth, leaf morphology, water use and tissue water relations of Eucalyptus globulus clones in response to water deficit. Tree Physiol. 21, 599-607.

Potts, B.M., Vaillancourt, R.E., Jordan, G.J., Dutkowski, G.W., Costa e Silva, J., McKinnon, G.E., Steane, D.A., Volker, P.W., Lopez, G.A., Apiolaza, L.A., Li, Y., Marques, C., Borralho, N.M.G., 2004. Exploration of the Eucalyptus globulus gene pool. In: Borralho, N.M.G., Pereira, J.S., Marques, C., Coutinho, J., Madeira, M., Tomé, M. (Eds.), Eucalyptus in a Changing World - IUFRO Conference. RAIZ, Instituto Investigação de Floresta e Papel, Aveiro, pp. 46-61.

Primer-e, 2002. Primer 5 for Windows, version 5.2.9. In: Primer-e.

Pryor, L.D., 1976. The Biology of Eucalypts. Edward Arnold, London.

Quinn, G.P., Keough, M.J., 2002. Experimental Design and Data Analysis for Biologists. Cambridge University Press, Cambridge.

Radich, M.C., 2007. Introdução e expansão do eucalipto em Portugal. In: Silva, J.S. (Ed.), Pinhais e Eucaliptais, a Floresta Cultivada. Público, FLAD, LPN, Lisbon, pp. 151-165.

Core Team R, 2012. R: a language and environment for statistical computing. R Foundation for Statistical Computing, Vienna.

Ribeiro, F., Tomé, M., 2000. Classificação climática de Portugal Continental, baseada em informação do Atlas do Ambiente. Revista de Ciências Agrárias 23, 3950.

Richards, M.B., Lamont, B.B., 1996. Post-fire mortality and water relations of three congeneric shrub species under extreme water stress - a trade-off with fecundity? Oecologia 107, 53-60.

Richardson, D.M., 1998. Forestry trees as invasive aliens. Conser. Biol. 12, 18-26.

Richardson, D.M., Pyšek, P., Rejmánek, M., Barbour, M.G., Panetta, F.D., West, C.J., 2000. Naturalization and invasion of alien plants: concepts and definitions. Diver. Distribut. 6, 93-107.

Ritter, M., Yost, J., 2009. Diversity, reproduction, and potential for invasiveness of Eucalyptus in California. Madroño 56, 155-167. 
Ryder, N.B., 1965. The cohort as a concept in the study of social change. Am. Sociol. Rev. 30, 843-861.

Schaie, K.W., 1984. Historical time and cohort effects. In: McCluskey-Fawcett, K.A., Reese, H.W. (Eds.), Life-span developmental psychology: historical and generational effects. Academic Press, New York, pp. 1-15.

Shakesby, R.A., Boakes, D.J., Coelho, C.D.O., Gonçalves, A.J., Walsh, R.P., 1996. Limiting the soil degradational impacts of wildfire in pine and eucalyptus forests in Portugal: a comparison of alternative post-fire management practices. Appl. Geogr. 16, 337-355.

Silva, J.S., Marchante, H., 2012. Post-fire management of exotic forests. In: Moreira, F., Heras, J., Corona, P., Arianoutsou, M. (Eds.), Post-Fire Management and Restoration of Southern European Forests. Springer, Dordrecht, pp. 223-255.

Silva, J.N., Feith, H., Pereira, J.C., 2007a. Exploração e silvicultura pós-fogo em eucaliptais. In: Alves, A.M., Pereira, J.S., Silva, J.N. (Eds.), O Eucaliptal em Portugal - Impactes Ambientais e Investigação Científica. ISAPress, Lisbon, pp. 285-312.

Silva, J.S., Sequeira, E., Catry, F., Aguiar, C., 2007b. Os contras. In: Silva, J.S. (Ed.), Pinhais e Eucaliptais, a Floresta Cultivada. Público, FLAD, LPN, Lisbon, pp. 221259.

Silva, J.S., Moreira, F., Vaz, P., Catry, F., Godinho-Ferreira, P., 2009. Assessing the relative fire proneness of different fores types in Portugal. Plant Biosyst. 143, 597-608.

Silva, J.S., Vaz, P., Moreira, F., Catry, F., Rego, F.C., 2011. Wildfires as a major driver of landscape dynamics in three fire-prone areas of Portugal. Landscape Urban Plan. 101, 349-358.

Sing, T., Sander, O., Beerenwinkel, N., Lengauer, T., 2009. ROCR: visualizing the performance of scoring classifiers. $\mathrm{R}$ package version 1.0-4.

Skolmen, R.G., Ledig, T., 1990. Eucalyptus globulus Labill. bluegum eucalyptus. In: Burns, R.H., B. (Ed.), Silvics of North America - Hardwoods. United States Department of Agriculture, Washington, DC, pp. 299-304.

Soares, P., Tomé, M., Pereira, J.S., 2007. A produtividade do eucaliptal. In: Alves, A.M., Pereira, J.S., Silva, J.M.N. (Eds.), O Eucaliptal em Portugal - Impactes Ambientais e Investigação Científica. ISAPress, Lisbon, pp. 27-60.

Stoneman, G.L., 1994. Ecology and physiology of establishment of eucalypt seedlings from seed: a review. Aust. Forest. 57, 11-29.

Stoneman, G.L., Dell, B., Turner, N.C., 1994. Mortality of Eucalyptus marginata (jarrah) seedlings in Mediterranean-climate forest in response to overstorey, site, seedbed, fertilizer application and grazing. Aust. J. Ecol. 19, 103-109.

Swets, J.A., 1988. Measuring the accuracy of diagnostic systems. Science 240, 12851293.

Taiz, L., Zeiger, E., 2002. Plant Physiology. Sinauer, Sunderland.
Tomé, M., 2000. Wood and non-wood production from plantation forests. In: Greene, T. (Ed.), Ecological and Socio-Economic Impacts of Close-to-Nature Forestry and Plantation Forestry: A Comparative Analysis. Scientific Seminar of the 7th Annual EFI Conference. European Forest Institute, Lisbon, pp. 37-55.

Tomé, M., Tomé, J.A., Araújo, M.C., Pereira, J.S., 1994. Intraspecific competition in irrigated and fertilized eucalypt plantations. Forest Ecol. Manage. 69, 211-218.

Tomé, M., Ribeiro, F., Soares, P., 2001. Modelo Globulus 2.1. In: Relatórios técnicocientíficos do GIMREF. Departamento Engenharia Florestal, Instituto Superior de Agronomia, Lisboa, pp. 96.

Turnbull, J.W., Pryor, L.D., 1984. Choice of species and seed sources. In: Hillis, W.E., Brown, A.G. (Eds.), Eucalypts for Wood Production. CSIRO Academic Press Melbourne, pp. 6-65.

Vallejo, V.R., Arianoutsou, M., Moreira, F., 2012. Fire ecology and post-fire restoration approaches in Southern European forest types. In: Moreira, F., Arianoutsou, M., Corona, P., Heras, J. (Eds.), Post-Fire Management and Restoration of Southern European Forests. Springer Verlag, Dordrecht, pp. 93119.

Virtue, J.G., Melland, R.L., 2003. The Environmental Weed Risk of Revegetation and Forestry Plants. Department of Water Land and Biodiversity Conservation, Adelaide.

Wang, D., Bachelard, E.P., Banks, J.C.G., 1988. Growth and water relations of seedlings of two subspecies of Eucalyptus globulus. Tree Physiol. 4, 129-138.

Wellington, A.B., Noble, I.R., 1985a. Post-fire recruitment and mortality in a population of the mallee Eucalyptus incrassata in semi-arid, south-eastern Australia. J. Ecol., 645-656.

Wellington, A.B., Noble, I.R., 1985b. Seed dynamics and factors limiting recruitment of the mallee Eucalyptus incrassata in semi-arid, south-eastern Australia. J. Ecol., 657-666.

Whelam, R.J., 1995. The Ecology of Fire. Cambridge University Press, Cambridge.

Whelam, R.J., Main, A.R., 1979. Insect grazing and post-fire plant succession in south-west Australian woodland. Aust. J. Ecol. 9, 387-398.

Williams, J.E., Brooker, M.I.H., 1997. Eucalypts: an introduction. In: Williams, J.E., Woinarski, J.C.Z. (Eds.), Eucalypt Ecology: Individuals to Ecosystems. Cambridge University Press, Cambridge, pp. 1-15.

Xanthopoulos, G., Calfapietra, C., Fernandes, P., 2012. Fire hazard and flammability of European forest types. In: Moreira, F., Heras, J., Corona, P., Arianoutsou, M. (Eds.), Post-Fire Management and Restoration of Southern European Forests, pp. 79-92.

Zar, J., 1996. Bistatistical Analysis. Prentice Hall, Upper Saddle River.

Zuur, A.F. Ieno, E.N., Walker, N.J., Saveliev, A.A., Smith, G.M., 2009. Mixed Effects Models and Extensions in Ecology with R. Springer Verlag, New York. 